\title{
Winter flounder settlement dynamics and the modification of settlement patterns by post-settlement processes in a NW Atlantic estuary
}

\author{
J. P. Manderson*, J. Pessutti, C. Meise, D. Johnson, P. Shaheen \\ NOAA/National Marine Fisheries Service, Ecosystem Processes Division, Behavioral Ecology Branch, \\ James J. Howard Marine Sciences Laboratory, Highlands, New Jersey 07732, USA
}

\begin{abstract}
For fishes with bipartite life cycles, locations of high quality nursery grounds are determined by processes controlling larval supply as well as those affecting early juvenile mortality and emigration. From April through June 2000, distributions of settling and early juvenile winter flounder Pseudopleuronectes americanus were measured to examine how pre- and post-settlement processes determine the location of the primary nursery ground in the Navesink River/Sandy Hook Bay estuarine system (NSBES), New Jersey. The settlement pattern, measured with fine mesh $(3 \mathrm{~mm})$ traps that captured flounder $\leq 8 \mathrm{~d}$ into the post-metamorphic age but excluded predators and prevented emigration, was spatially dynamic. Fish settled on organically rich substrata (organic content $=5$ to $12 \%$ by weight) 2 wk earlier in the Navesink River (mid-April through mid-May) than on similar substrata just $15 \mathrm{~km}$ downstream in Sandy Hook Bay (May through mid-June). Local retention mechanisms combined with spatial variation in spring warming, which probably affected larval-stage durations, appeared to be responsible for the dynamic settlement pattern. To determine whether spatial patterns of flounder settlement were dramatically altered by post-settlement processes, we compared settler supply (measured using traps) with juvenile distributions (measured using beam trawls, which do not prevent post-settlement mortality and emigration). The index of settler supply explained $95 \%$ of the variation in juvenile abundance patterns in the Navesink River $(p<0.001)$ where larger juveniles $>20 \mathrm{~mm}$ standard length were commonly trawled. However, larger juveniles were nearly absent in Sandy Hook Bay, where juvenile distributions were not related to settlement $\left(r^{2}=0.15, p=0.31\right)$. Thus, the upstream distribution of juvenile winter flounder in the NSBES, which is similar to that observed in other estuarine nurseries, appeared to be produced by the rapid modification of settlement patterns by post-settlement processes. However, pre-settlement processes that produce spatial variation in the timing of settlement could affect the ways in which settlement patterns are modified by age, time and/or size dependent post-settlement processes.
\end{abstract}

KEY WORDS: Dynamic habitat $\cdot$ Nursery $\cdot$ Supply side processes $\cdot$ Post-settlement processes

\section{INTRODUCTION}

Most marine demersal fishes and invertebrates have complex life histories in which eggs hatch dispersive larvae that metamorphose and settle as relatively sedentary juveniles. For these species, locations of primary nursery grounds are established by processes controlling larval supply and settlement.
Settlement patterns may remain stable through the early juvenile period or may be dramatically altered by spatially structured mortality and/or emigration during the first few days to weeks of demersal life (Levin 1994, Wennhage \& Pihl 2001, Booth 2002, Moksnes 2002, Steele \& Forrester 2002, Webster 2002). As a result, better understanding of processes controlling nursery-ground formation often demands 
simultaneous assessment of the ways in which early juvenile distributions are shaped by supply-side and post-settlement processes. Relationships between preand post-settlement processes and year-class strength in fishes and invertebrates, including mobile flatfishes, have been extensively studied (Zijlstra et al. 1982, van der Veer 1986, Houde 1987, Beverton \& Iles 1992, Hines \& Ruiz 1995, Jager et al. 1995, Nash \& Geffen 2000, van der Veer et al. 2000). However, studies of the combined effects of pre- and early post-settlement processes on the spatial distributions of juveniles have largely been confined to siteattached invertebrates and reef fishes (Caselle \& Warner 1996, Eggleston et al. 1998, Shima 2001, Steele et al. 2002. but see Wennhage 2002).

Winter flounder Pleuronectes americanus is a NW Atlantic flatfish that ranges from Labrador to Georgia. With the exception of populations on Georges Bank and Nantucket shoals, the species uses estuaries as primary spawning and nursery grounds (Howe et al. 1976, Pierce \& Howe 1977, Pereira et al. 1999). Adults spawn demersal eggs in the upper reaches of estuaries during winter and spring (Saila 1961, Crawford \& Kerry 1985, Scarlett 1991, Phelan 1992, Stoner et al. 1999). Pelagic larvae remain in the water column from 5 to $8 \mathrm{wk}$ and larval duration is strongly temperaturedependent (Laurence 1975, Keller et al. 1999, Chambers et al. 2001). Studies of estuarine circulation and larval distributions suggest that larvae are retained near spawning grounds (Pearcy 1962, Crawford \& Kerry 1985, Chant et al. 2000), where they settle as benthic juveniles during the spring and early summer (Lobell 1939, Perlmutter 1947, Saila 1961, Pearcy 1962). Juveniles are generally more abundant in upstream reaches of estuaries, which are considered to be primary nursery grounds (Pearcy 1962, Armstrong 1995, Meng \& Powell 1999, Stoner et al. 2001). Although these studies suggest that early juvenile winter flounder habitat associations are primarily determined by supply side processes, the extent to which postsettlement processes also contribute to the formation of upstream nursery grounds has not been explored.

We studied contributions of supply-side and early post-settlement processes to the formation of a winter flounder nursery ground in a mid-Atlantic estuarine system. We used settlement traps that captured newly settled fish but limited predation and emigration to test the null hypothesis that settler supply did not vary in space and time throughout the estuary. We then determined whether early juvenile flounder distributions were primarily controlled by supply-side processes by comparing settlement patterns, measured using traps, with juvenile distributions, measured using fine-mesh trawls that do not limit post-settlement mortality or emigration.

\section{MATERIALS AND METHODS}

Study area and study design. We used a nested experimental design to examine abundance patterns of settlement and juvenile stage winter flounder in the Navesink River/Sandy Hook Bay estuarine system (NSBES), a known spawning and nursery ground for the species (Fig. 1; Phelan 1992, Stoner et al. 1999, 2001, Sogard et al. 2001, Manderson et al. 2002). The study area was divided into 6 sectors along gradients of salinity, depth, and sediment characteristics associated with changes in fish and invertebrate community structure (Fig. 1; see Manderson et al. 1997 for details). Sectors A and B were located in Sandy Hook Bay in deep, high salinity areas with fine sand and silty substrata. Sediments are generally more coarse in Sector A, which contains the navigational channel to the Atlantic Ocean. Sediments are also fine sands and silts in Sectors E and F, located in shallow, lower salinity areas of the Navesink River. The primary freshwater source for the river drains into Sector F, where salinities are relatively low. Networks of sandbars and channels with high-velocity tidal currents are characteristic of Sectors $\mathrm{C}$ in the inner bay and D in the lower river, where sediments are coarse and medium sands. Three sectors were nested within 2 regions; the bay (Sectors A, B, C) and river (Sectors D, E, F; Fig. 1).

In each sector we randomly selected 3 stations from transects previously used in synoptic surveys (Fig. 1; Manderson et al. 1997, Stehlik \& Meise 2000, Stoner et al. 2001). Thus, 3 stations were nested within each of 3 sectors, nested within each of 2 regions. This hierarchical design allowed for analysis of flounder abundance at 3 spatial scales (among regions, $\bar{x}$ distance $[D]=$ $10.9 \mathrm{~km} \pm 3.5$; among sectors, $\bar{x} \mathrm{D}=4.1 \mathrm{~km} \pm 1.3$; among stations, $\bar{x} \mathrm{D}=1.7 \mathrm{~km} \pm 0.8$ ).

Collection techniques. Newly settled fish: We measured patterns in the supply of settlement-stage winter flounder with traps that captured newly settled fish $<14 \mathrm{~mm}$ standard length (SL) but excluded predators. The traps were constructed of rectangular $3 \mathrm{~mm}$ nylon mesh bags $(0.75 \times 0.75 \times 0.40 \mathrm{~m})$ secured within steel reinforcing bar frames $(0.85 \times 0.85 \times 0.45 \mathrm{~m})$. The mesh bags had zippers that were tightly closed when the traps were deployed. Two to $3 \mathrm{~cm}$ of sediment penetrated through the bottoms of traps deployed on the substratum (see Able et al. 1999). The mesh size allowed fish $<3 \mathrm{~mm}$ in body depth $\left(\mathrm{BD}_{i} \leqslant 13 \mathrm{~mm}\right.$ standard length [SL]; $\mathrm{SL}$ in $\mathrm{mm}=1.68 \times \mathrm{BD}$ in $\mathrm{mm}+6.09$, $\mathrm{R}^{2}=0.67$ ) to enter the traps. Fish growing to $3 \mathrm{~mm} \mathrm{BD}$ (SL $\sim 14 \mathrm{~mm}$ ) were retained in the gear. Winter flounder larvae undergo eye migration and metamorphosis from 7 to $13 \mathrm{~mm}$ SL (1 to $3 \mathrm{~mm} \mathrm{BD;} \mathrm{Chambers} \mathrm{\&}$ Leggett 1987, Able \& Fahay 1998) and slightly larger fish (17 to $28 \mathrm{~mm} \mathrm{SL}$ ) grow $\sim 0.8 \mathrm{~mm} \mathrm{SL} \mathrm{d}^{-1}$ in enclo- 
sures identical to the traps (Manderson et al. 2002). Thus the traps captured fish during and just after settlement.

We fished replicate settlement traps $(\mathrm{N}=3)$ at the 18 stations during eight, $13 \mathrm{~d}$ experiments conducted from March 7 through June 27, 2000 (Table 1). During each experiment the traps were retrieved after $13 \mathrm{~d}$, emptied of flounder and other organisms, washed with freshwater and redeployed the following day. We measured (SL and $\mathrm{BD}$ in $\mathrm{mm}$ ) trapped flounder and preserved them in $95 \%$ ethanol for age determination using otolith increment analysis.

We estimated post-metamorphic ages of trapped flounder by counting increments external to accessory primordia in sagittae otoliths. Accessory primordia form in the otoliths of fish undergoing eye-migration and settlement from pelagic to benthic habitats (Chambers \& Leggett 1987, Sogard 1991). Otolith increments are then deposited daily in newly settled flounder with growth rates exceeding 0.25 $\mathrm{mm} \mathrm{SL} \mathrm{d}^{-1}$ (Sogard 1991). We extracted left sagittae otoliths from 2 fish selected at random from each trap collection. Otoliths were embedded in Crystal Bond thermoplastic glue and then polished with sandpaper (800 and 1200 grit) and alumina powder $(0.3 \mu)$ along

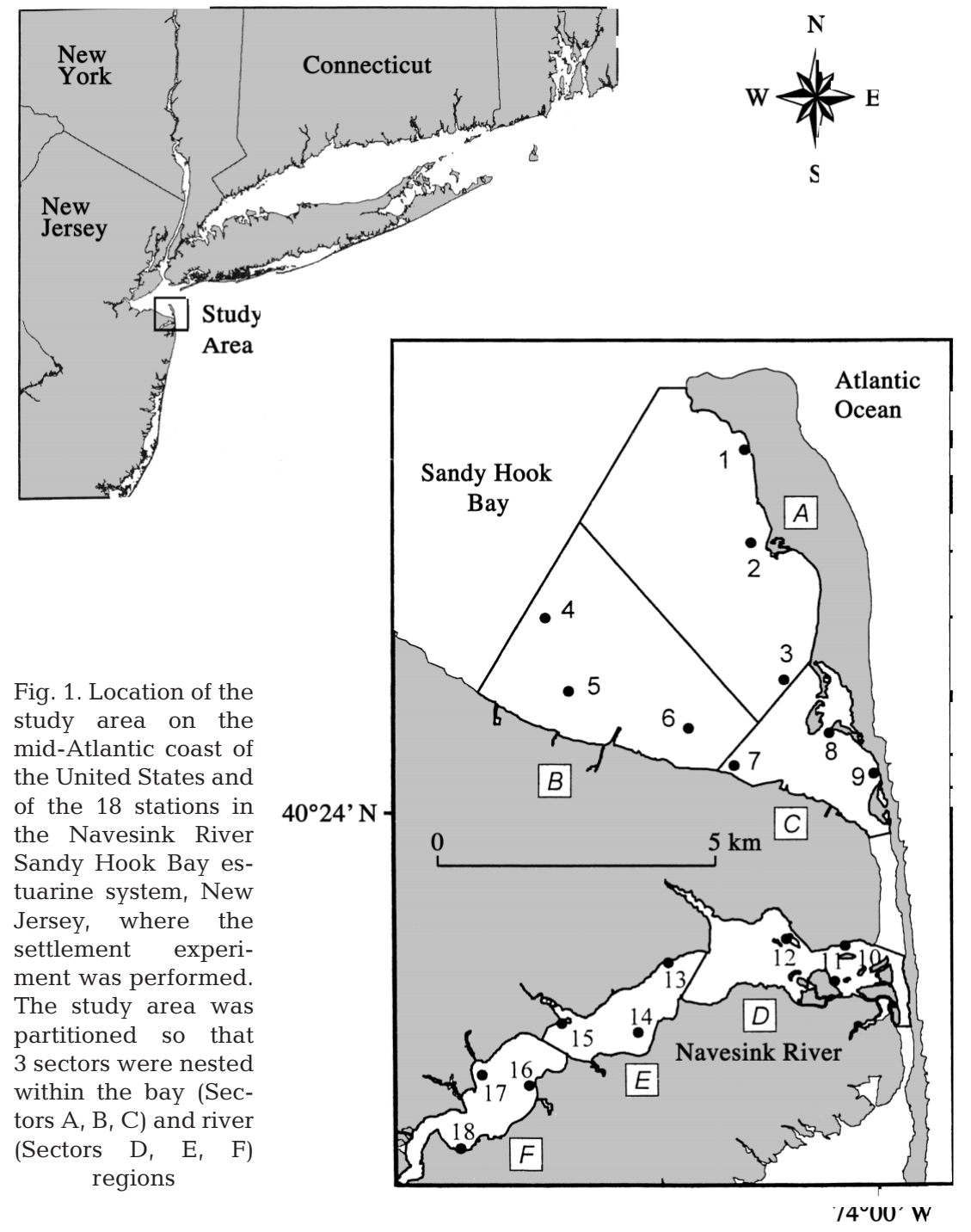

Table 1. Pseudopleuronectes americanus. Dates of winter flounder sampling and processes measured with settlement traps and beam trawls in the Navesink Sandy Hook Bay estuarine system. Beam trawls were also used to measure abundances of potentially important crustacean predators

\begin{tabular}{|c|c|c|}
\hline $\begin{array}{r}\text { Gear: } \\
\text { Process: }\end{array}$ & $\begin{array}{c}\text { Settlement traps } \\
\text { Settlement }\end{array}$ & $\begin{array}{c}1 \mathrm{~m} \text { beam trawl } \\
\text { Settlement }+ \\
\text { mortality and emigration }\end{array}$ \\
\hline Expt & Duration & Sampling dates \\
\hline 1 & March 7-21 & March 15 \\
\hline $2^{\mathrm{a}}$ & March 22-April 3 & March 29 \\
\hline 3 & April 4-18 & April 12 \\
\hline $4^{\mathrm{a}}$ & April 19-May 1 & April 25 \\
\hline 5 & May 2-16 & May 9 \\
\hline $6^{a}$ & May 17-30 & May 24 \\
\hline 7 & May 31-June 13 & June 5 \\
\hline $8^{a}$ & June $14-28$ & June 19 \\
\hline 9 & & July 5 \\
\hline \multicolumn{3}{|c|}{$\begin{array}{l}\text { a Replicate }(\mathrm{N}=3) \text { sediment cores were collected at each } \\
\text { station during the experiment }\end{array}$} \\
\hline
\end{tabular}

the sagittal plane until the cores were exposed. Otolith increments were counted 3 times under $400 \times$ and $1000 \times$ magnification.

Juvenile flounder and potential crustacean predators: We used a $1 \mathrm{~m}$ beam trawl (3 $\mathrm{mm}$ mesh liner) to measure flounder distributions established at settlement but potentially modified by predation and emigration. During each trapping experiment, replicate trawl tows $\left(\mathrm{N}=3\right.$; speed $=1 \mathrm{~m} \mathrm{~s}^{-1}$, duration $=30 \mathrm{~s}$ ) were made at the stations (Table 1). An additional trawl survey was conducted on July 5 . We measured (in $\mathrm{mm}$ ) and counted all organisms and expressed abundance as number of individuals $10 \mathrm{~m}^{-2}$ of tow. Densities of sand shrimp Crangon septemspinosa $>30 \mathrm{~mm}$ total length (TL), and blue crabs Callinectes sapidus, which are potentially important predators of newly settled winter flounder ( $<20 \mathrm{~mm} \mathrm{SL}$; Bertram \& Leggett 1994, Witting 1995, Witting \& Able 1995), were also measured with the beam trawls. 
Habitat variation: Hourly bottom water temperatures $\left({ }^{\circ} \mathrm{C}\right)$ were measured at the stations throughout the study with electronic recorders (Onset). We measured salinity (\%) with a probe (Yellow Springs Instruments) $\geq 4$ times at the stations during each experiment. Depths were measured with an electronic depth finder and corrected to mean low water. We also collected replicate sediment cores $(\mathrm{N}=3,2.5 \mathrm{~cm}$ diameter) at each station (Table 1). Sieve fractionation was performed on the sediments to calculate mean grain sizes and sorting coefficients using the methods of Folk (1980). Dry sediment was incinerated at $500^{\circ} \mathrm{C}$ to measure organic content (\% dry wt).

Analysis. Capture efficiency of settlement traps: Variability in the growth of settled fish inside the traps could have influenced capture efficiency. As a result we examined the relationship between the growth of marked winter flounder (17 to $27 \mathrm{~mm} \mathrm{SL} ; \bar{x} \mathrm{~mm} \mathrm{SL} \mathrm{d}^{-1}$ trap $^{-1}$ ) and numbers of settlers in traps deployed throughout the NSBES in two 12 d experiments conducted from mid-May through mid-June 1999 (see Manderson et al. 2002 for details). Settler abundance in the traps was not related to the growth of marked fish in these experiments (Pearson's $r \leq 0.21, \mathrm{p} \geq 0.54$ ).

Abundance patterns in space and time: We analyzed flounder and crustacean abundance patterns with nested ANOVA using experiment, region and sector as fixed factors and station as a random factor. Trawled flounder were divided into recently settled $(\leq 20 \mathrm{~mm}$ SL) and juvenile (>20 mm SL) size classes. Experiments in which animals were absent were eliminated from analyses. Levene's tests for heteroscedasticity (Wilkerson 1997) showed that variances were homogenized with $\log _{e}(n+1)$ transformation. The region term was not used in analyses of juvenile flounder $>20 \mathrm{~mm}$ SL and blue crabs, which were rarely trawled in Sandy Hook Bay. We calculated expected mean squares (MS) to determine appropriate error MS and degrees of freedom (df) for all F-tests (Table 2).

Relationship between settlement and habitat variation: We explored relationships between flounder settlement and habitat variation with a generalized additive model (GAM; Hastie \& Tibshirani 1990, Venables \& Ripley 1997). Numbers of newly settled flounder in traps served as the dependent variable. Station depth $(\mathrm{m})$, salinity $(\%)$, sediment organic content $(\%$ by weight) and grain size $(\varphi)$, and temperature $\left({ }^{\circ} \mathrm{C}\right)$ expressed as relative degree days were considered as independent variables. Winter flounder larvae incubated at temperatures $\leq 2^{\circ} \mathrm{C}$ in the laboratory fail to metamorphose (Laurence 1975). Thus, relative temperature degree days (TDD) were calculated for the stations on days of trap retrieval as the cumulative average daily temperature above $2^{\circ} \mathrm{C}$ from the start of the experiment on March 7.
Table 2. Pseudopleuronectes americanus. Nested ANOVA of the abundance of early life history stages of winter flounder and potentially important crustacean predators in the Navesink Sandy Hook Bay estuarine system

\begin{tabular}{|c|c|c|c|c|}
\hline $\begin{array}{l}\text { Life history stage [gear] } \\
\text { (source of variation) }\end{array}$ & df & MS & $F$ & $\mathrm{p}$ \\
\hline \multicolumn{5}{|l|}{ Newly settled founder [traps] ${ }^{\mathrm{b}}$} \\
\hline Region & 1 & 7.23 & 4.63 & 0.07 \\
\hline Sector(Region) & 4 & 1.76 & 1.13 & 0.43 \\
\hline Station(Sector(Region)) & 6 & 1.56 & 10.71 & $<0.001$ \\
\hline Experiment & 4 & 4.77 & 4.44 & 0.007 \\
\hline Experiment $\times$ Region & 4 & 5.59 & 5.21 & 0.004 \\
\hline Experiment $\times$ Sector(Region) & 16 & 0.59 & 0.55 & 0.893 \\
\hline Experiment $\times$ Station(Sector(Region)) & 24 & 1.07 & 7.35 & $<0.001$ \\
\hline Error & 210 & 0.15 & & \\
\hline Total & 269 & & & \\
\hline \multicolumn{5}{|c|}{ Recently settled flounder $\leq 20 \mathrm{~mm} \mathrm{SL}$ [beam trawls] ${ }^{\mathrm{b}}$} \\
\hline Region & 1 & 0.03 & 0.58 & 0.48 \\
\hline Sector(Region) & 4 & 0.19 & 3.57 & 0.08 \\
\hline Station(Sector(Region)) & 6 & 0.06 & 1.71 & 0.15 \\
\hline Experiment & 4 & 0.11 & 6.14 & 0.002 \\
\hline Experiment $\times$ Region & 4 & 0.12 & 6.71 & $<0.001$ \\
\hline Experiment $\times$ Sector(Region) & 16 & 0.04 & 2.28 & 0.032 \\
\hline Experiment $\times$ Station(Sector(Region)) & 24 & 0.02 & 0.57 & 0.95 \\
\hline Error & 210 & 0.03 & & \\
\hline Total & 269 & & & \\
\hline \multicolumn{5}{|c|}{ Juvenile flounder $>20 \mathrm{~mm}$ SL [beam trawls] $]^{\mathrm{a}, \mathrm{c}}$} \\
\hline Sector & 2 & 0.16 & 3.36 & 0.105 \\
\hline Station(Sector) & 6 & 0.05 & 2.56 & 0.024 \\
\hline Experiment & 4 & 0.12 & 2.07 & 0.116 \\
\hline Experiment $\times$ Sector & 8 & 0.10 & 1.71 & 0.147 \\
\hline Experiment $\times$ Station(Sector) & 24 & 0.06 & 3.07 & $<0.001$ \\
\hline Error & 90 & 0.02 & & \\
\hline Total & 134 & & & \\
\hline \multicolumn{5}{|l|}{ Sand shrimp $>30 \mathrm{~mm}$ SL [beam trawls] ${ }^{\mathrm{b}}$} \\
\hline Region & 1 & 12.21 & 19.48 & 0.004 \\
\hline Sector(Region) & 4 & 0.84 & 1.34 & 0.36 \\
\hline Station(Sector(Region)) & 6 & 0.63 & 1.28 & 0.27 \\
\hline Experiment & 8 & 3.36 & 9.44 & $<0.001$ \\
\hline Experiment $\times$ Region & 8 & 1.04 & 2.91 & 0.01 \\
\hline Experiment $\times$ Sector(Region) & 32 & 0.51 & 1.43 & 0.13 \\
\hline Experiment $\times$ Station(Sector(Region)) & 48 & 0.36 & 0.73 & 0.91 \\
\hline Error & 252 & 0.47 & & \\
\hline Total & 359 & & & \\
\hline \multicolumn{5}{|l|}{ Blue crabs [beam trawls] $]^{a, c}$} \\
\hline Sector & 2 & 3.2 & 5.71 & 0.04 \\
\hline Station(Sector) & 6 & 0.56 & 2.32 & 0.035 \\
\hline Experiment & 8 & 0.25 & 0.77 & 0.630 \\
\hline Experiment $\times$ Sector & 16 & 0.16 & 0.514 & 0.927 \\
\hline Experiment $\times$ Station (Sector) & 48 & 0.32 & 1.33 & 0.098 \\
\hline Error & 162 & 0.24 & & \\
\hline Total & 198 & & & \\
\hline \multicolumn{5}{|c|}{$\begin{array}{l}{ }^{a} \text { Region term dropped from analyses because individuals were nearly } \\
\text { absent from the bay } \\
\text { (F-tests for sources of variation: }\end{array}$} \\
\hline \multicolumn{5}{|c|}{$\begin{array}{l}{ }^{\mathrm{b}} \text { Region and Sector(Region) tested with Station(Sector(Region)) MS } \\
\text { and DF; Experiment, Experiment } \times \text { Region and Experiment } \times \text { Sec- } \\
\text { tor(Region) tested with Experiment } \times \text { Station(Sector(Region)) MS and } \\
\text { DF; Station(Sector(Region)) and Experiment } \times \text { Station(Sector(Region)) } \\
\text { tested with error MS and DF }\end{array}$} \\
\hline \multicolumn{5}{|c|}{$\begin{array}{l}{ }^{\mathrm{C}} \text { Sector tested with Station(Sector) MS and DF; Experiment and Exper- } \\
\text { iment } \times \text { Sector tested with Experiment } \times \text { Station(Sector) MS and DF; } \\
\text { Station(Sector) and Experiment } \times \text { Station(Sector)tested with error } \\
\text { MS and DF }\end{array}$} \\
\hline
\end{tabular}


We constructed the GAM with manual forward stepwise selection using a cubic spline with 4 degrees of freedom, which produced moderate smoothing (S-Plus, Math-Soft; Hastie \& Tibshirani 1990, Venables \& Ripley 1997). The term added to the model at each step resulted in the largest significant $(p<0.05)$ reduction in residual deviance ( variance) when compared to the previous model using an approximate F-test in analysis of deviance (Hastie 1992). We calculated deviance explained as null deviance minus residual deviance divided by null deviance. First-order interactions between significant variables were also tested. Partial additive effects of the independent variables were plotted with \pm 2 SE confidence bands.

To identify possible centers of winter flounder settlement, we used Arcview GIS software (ESRI) to project GAM based estimates of daily settlement across the estuary. For each date, a continuous surface of cumulative TDD (cell size $=500 \mathrm{~m}$ ) was constructed using temperature records for the geo-referenced stations and Arcview's inverse distance weighted averaging algorithm. We used the same method to construct a continuous surface of sediment organic content using data from a 1997 sediment survey conducted at 84 stations throughout the NSBES (see Stoner et al. 2001). Sediment organic contents measured at stations in this study were similar to cell based estimates generated from the 1997 sediment survey (Pearson's $\mathrm{r}=0.85, \mathrm{p} \ll$ 0.001). Grid-cell values for the 2 variables were exported from Arcview and used in the GAM to estimate daily settlement patterns. These estimates were returned to Arcview for plotting.

Relationship between the supply of settlers and juvenile flounder distributions: To determine whether spatial patterns of settlement were maintained through the early juvenile period, we used Kendall's coefficient of concordance and regression analysis to compare trawl based estimates of flounder density, with settler supply measured as the cumulative abundance of fish in traps.

\section{RESULTS}

\section{Trap collections and patterns of settler supply}

Newly settled flounder were trapped from mid-April through mid-June $(\mathrm{N}=299)$. The fish ranged in length from 5 to $29 \mathrm{~mm}$ SL (median $=18 \mathrm{~mm}$ ) and most had body depths exceeding $4 \mathrm{~mm}$ (median $=7 \mathrm{~mm}, 2$ to $11 \mathrm{~mm}$; Fig. 2a). Fish collected during the $13 \mathrm{~d}$ trap deployments ranged in age from 4 to $14 \mathrm{~d}$ post eyemigration (median $=10 \mathrm{~d}_{i}$ Fig. $2 \mathrm{~b}$ ). Their growth rates averaged $1.3 \mathrm{~mm} \mathrm{SL} \mathrm{d}^{-1}(\mathrm{SE}=0.1)$.

We also trapped sand shrimp, amphipods and polychaetes. Shrimp were captured infrequently and were too small ( $\mathrm{N}=64 ; 2$ to $13 \mathrm{~mm} \mathrm{TL}$ ) to consume newly settled winter flounder (Witting \& Able 1993, 1995, Bertram \& Leggett 1994).

\section{Settlement dynamics}

Flounder settlement measured with the traps was spatially dynamic (Fig. 3, Table 2). Settlement occurred earlier in the river than the bay and the trial by region interaction accounted for a large amount of variation in the ANOVA (21\% of total variance [TV]).
Fig. 2. Pseudopleuronectes americanus. Frequencies of (A) size and (B) age posteye migration for newly settled winter flounder collected in the settlement traps $(\mathrm{N}=299)$. Open symbol with lines in (A) indicates the range of lengths and body depths for settlement-stage fish reported by Chambers \& Leggett (1987)
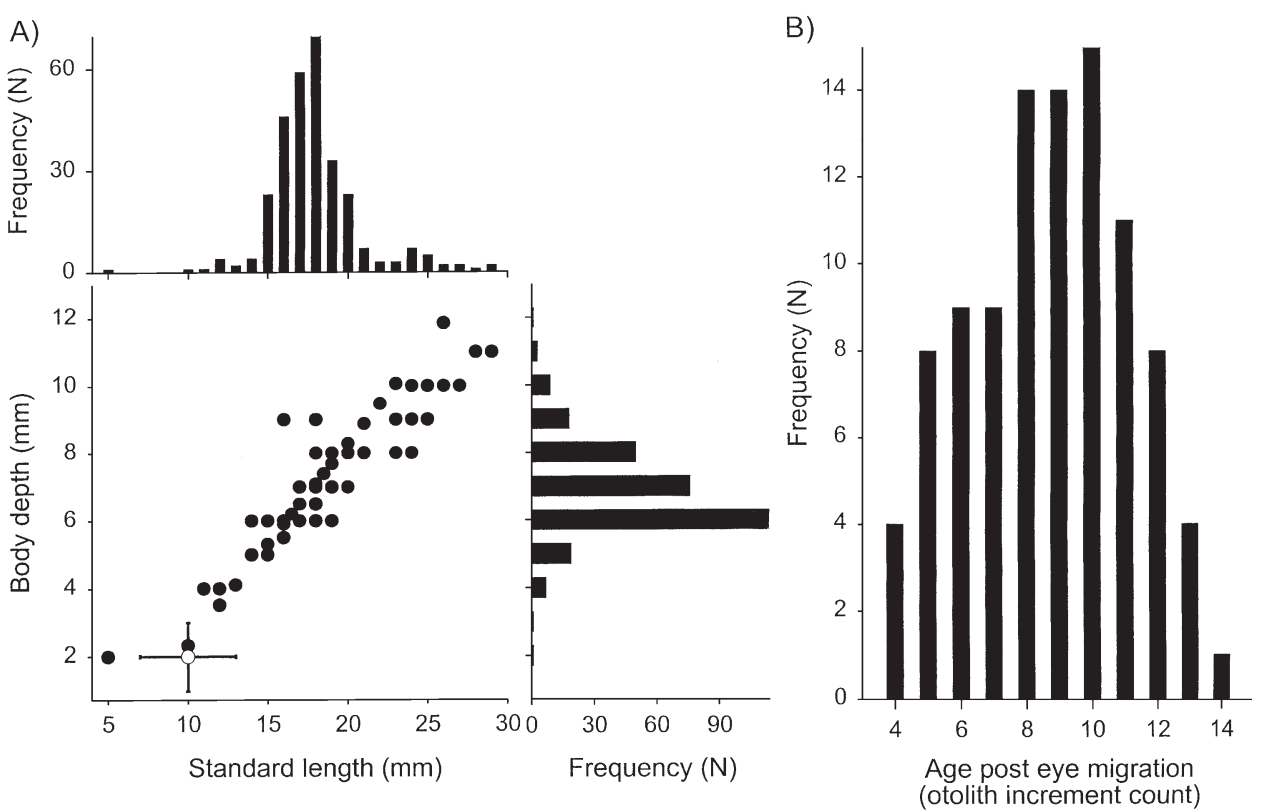


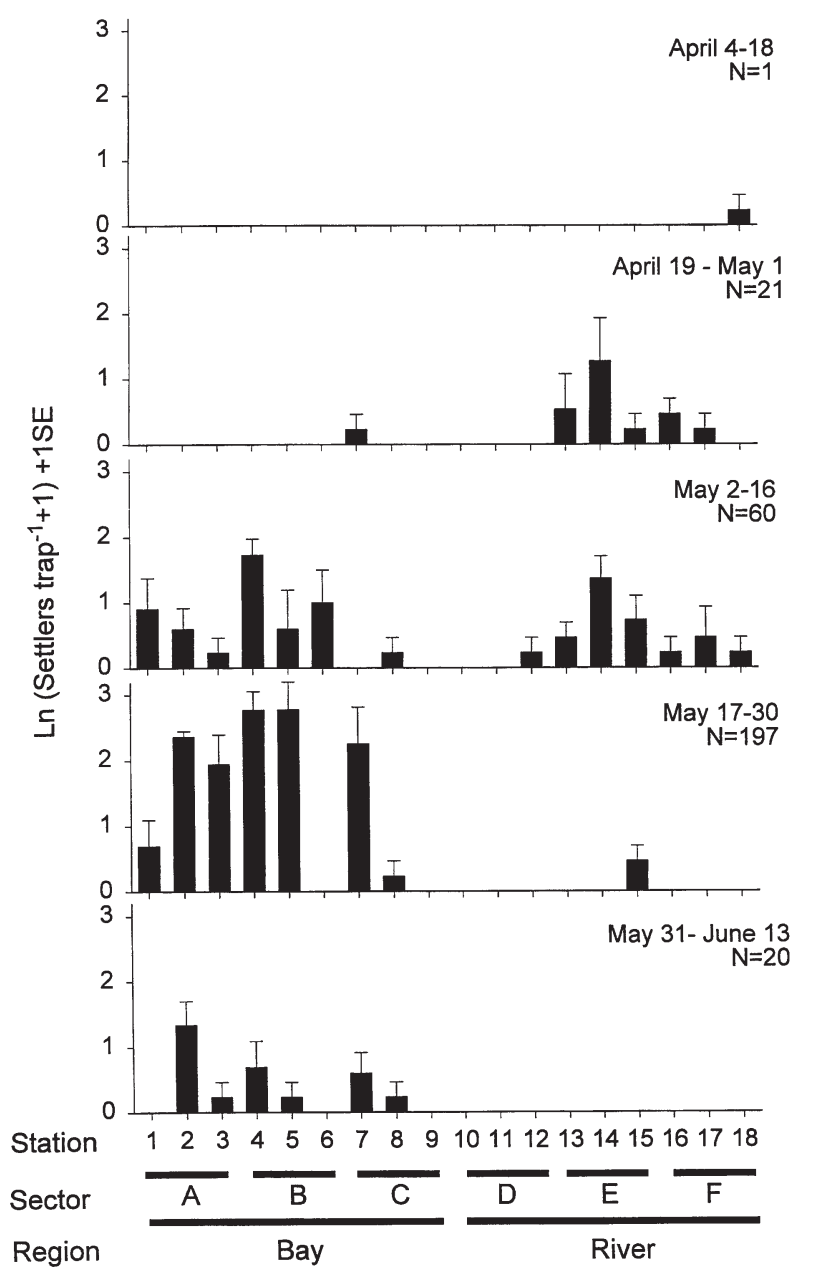

Fig. 3. Pseudopleuronectes americanus. Abundance of newly settled winter flounder in settlement traps, which was dynamic in time at a regional spatial scale, with earlier settlement in the Navesink River than Sandy Hook Bay (see Table 2). (Fig. 1 for station locations. Experiments in which fish were absent from traps are not included)

Newly settled fish were primarily collected in the river from April 18 through May 1. Abundance peaked in the river on May 16, when values were

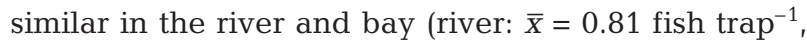
$\mathrm{SE}=0.26$; bay: $\bar{x}=1.41$ fish $\operatorname{trap}^{-1}, \mathrm{SE}=0.40$ ). On May 30 and June 13 most fish were trapped in the bay. Settlement peaked in the bay on May 30, when abundance in the region $\left(\bar{x}=7.22\right.$ fish $\left.\operatorname{trap}^{-1}, \mathrm{SE}=1.70\right)$ was nearly an order of magnitude higher than in the river on May 16.

Newly settled fish were rare in Sector D of the river, but the effects of sector within region were insignificant in the ANOVA (Fig. 3, Table 2). Settler abundance was highly variable among stations within sectors in time $(40 \% \mathrm{TV})$.

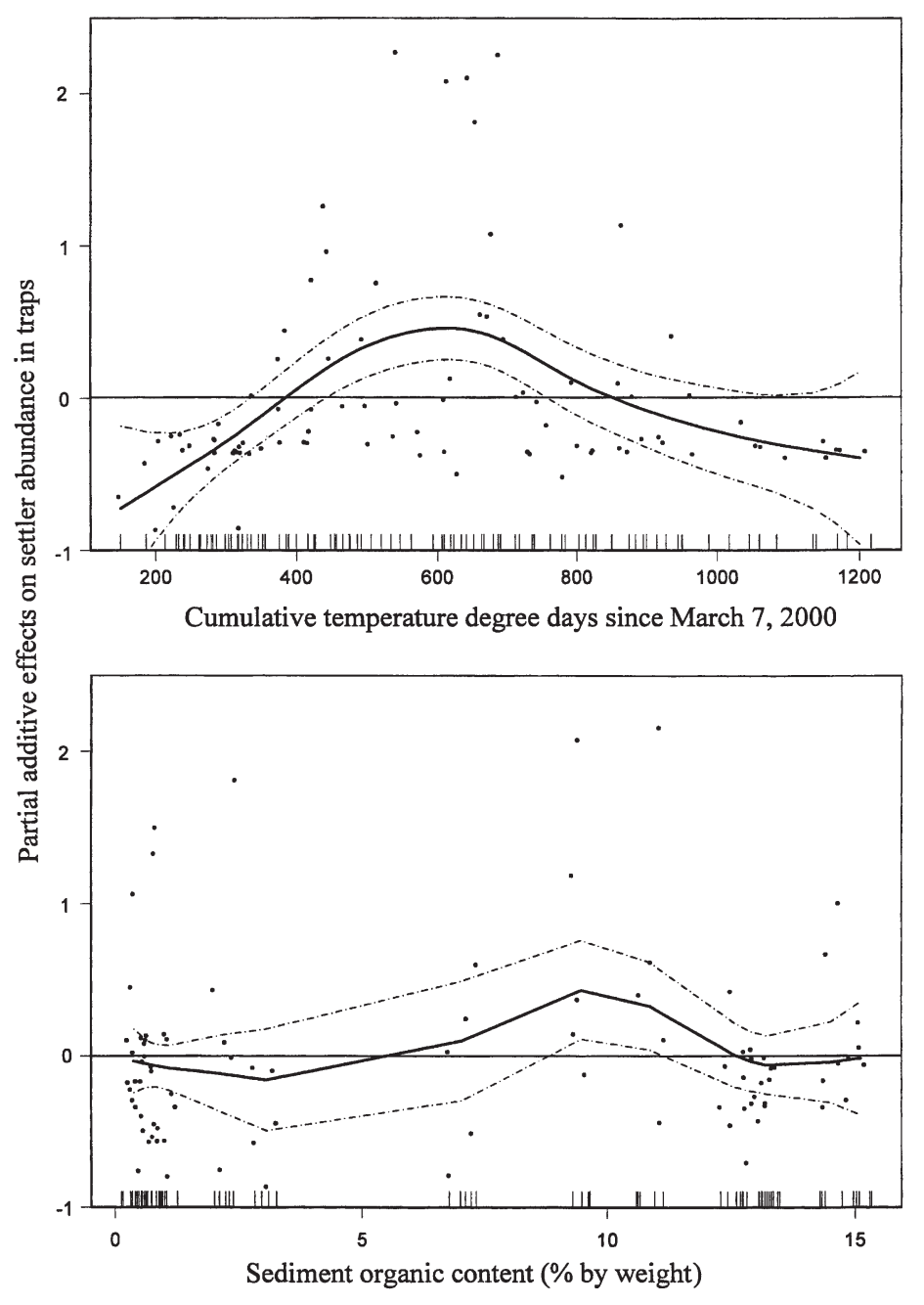

Fig. 4. Pseudopleuronectes americanus. Generalized additive model (GAM) based partial additive effects showing that relative temperature degree days between 350 and 850, and sediment organic contents between 5 and $12 \%$ by weight, had positive effects on the abundance of newly settled flounder in traps (see Table 3)

\section{Dynamic habitat and likely centers of flounder settlement}

Settlement was significantly related to relative TDD and sediment organic content (Table 3). Settlement showed a strong unimodal response to TDD and most fish were trapped from 350 to 875 TDD (maximum = 625 TDD; Fig. 4). Settlement was also marginally higher on organically rich substrata (5 to $12 \%$ by weight).

Rates of bottom water warming and TDD accumulation were more rapid in the river than the bay. Mean daily warming rates were positively correlated with distance upstream (Pearson's $r=0.60, p=0.01$; Fig. 5a), and degree day values within the range of positive effects in the GAM occurred 2 wk earlier in the river 
Table 3. Pseudopleuronectes americanus. Generalized additive model showing that the abundance of newly settled winter flounder in traps was significantly related to relative temperature degree days and sediment organic content in the Navesink River/Sandy Hook Bay estuarine system (NSBES) (see Fig. 5a). The null model assumed that settlement variation was not explained by habitat

\begin{tabular}{|c|c|c|c|c|c|}
\hline \multirow[b]{2}{*}{ Model } & \multirow[b]{2}{*}{ df } & \multirow[b]{2}{*}{$F$} & \multirow[b]{2}{*}{$\mathrm{p}$} & \multicolumn{2}{|c|}{ Non-parametric } \\
\hline & & & & Deviance & $\begin{array}{c}\text { Deviance } \\
\text { explained (\%) }\end{array}$ \\
\hline Null & & & & 41.17 & \\
\hline Degree days since March 7 & 3 & 9.69 & $\ll 0.001$ & 10.69 & 26 \\
\hline + sediment organic content & 3 & 3.61 & 0.016 & 3.69 & 9 \\
\hline Total Explained & & & & 14.20 & 35 \\
\hline Residual & & & & 26.97 & 65 \\
\hline Degree days since March 7 & & & & & \\
\hline + sediment grain size & 3 & 2.24 & 0.090 & & \\
\hline+ depth & 3 & 2.20 & 0.094 & & \\
\hline + salinity & 3 & 1.68 & 0.178 & & \\
\hline
\end{tabular}
parameters

until mid-May. High settlement probably also occurred on similar substrata in the center of the bay from mid-May through mid-June.

\section{Beam trawl collections}

Flounder $(\mathrm{N}=122 ; 5$ to $59 \mathrm{~mm} \mathrm{SL})$ were trawled throughout the estuary. Abundance patterns for recently settled fish $\leq 20 \mathrm{~mm}$ SL were spatially dynamic and broadly similar to the trapping pattern (Fig. 7a, Table 2). Newly settled fish were collected in the river from April 11 through May 23, in the bay from May 9 through June 5 , and the trial $\times$ region interaction accounted for a large portion of

(April 21 to June 5) than the bay (May 2 to June 21). Substrata with organic contents of 5 to $12 \%$ occur in the middle and upper reaches of the river and center of the bay (Fig. 5b).

Two likely centers of flounder settlement located in the middle reach of the river and center of the bay were identified when cell-based estimates of TDD and organic carbon content were used to project the GAM across the estuary (Fig. 6). The projections showed that settlement probably began on organically rich substrata in the middle reach of the river in late April and continued there explained variation in the ANOVA (9.6\% TV). However, in contrast with the trapping results, peak densities of recently settled fish were similar in the 2 regions (river, April 25: $\bar{x}=0.96$ per $10 \mathrm{~m}^{2}, \mathrm{SE}=0.47$; bay, May 23: $\bar{x}=0.52$ per $10 \mathrm{~m}^{2}, \mathrm{SE}=0.22$ ). Fish $\leq 20 \mathrm{~mm}$ SL were rare in Sectors $C$ in the bay and D in the river, but abundance varied among sectors within regions in time.

Juvenile flounder > $20 \mathrm{~mm}$ SL were commonly trawled in the river from May 9 through the last survey on July 5 (Fig. 7b). However, fish of this size were nearly absent in
Fig. 5. Pseudopleuronectes americanus. Variability in space and time of habitat characteristics related to settlement dynamics in the generalized additive model (GAM). (A) From March 7 through July 5, 2000, bottom temperatures warmed and degree days accumulated more rapidly upstream in the Navesink River than downstream in Sandy Hook Bay. (B) Sediment organic values are typically within the range of positive effects in the GAM (5 to $12 \%$ by weight) in the central part of the bay and the middle and upper reaches of the river

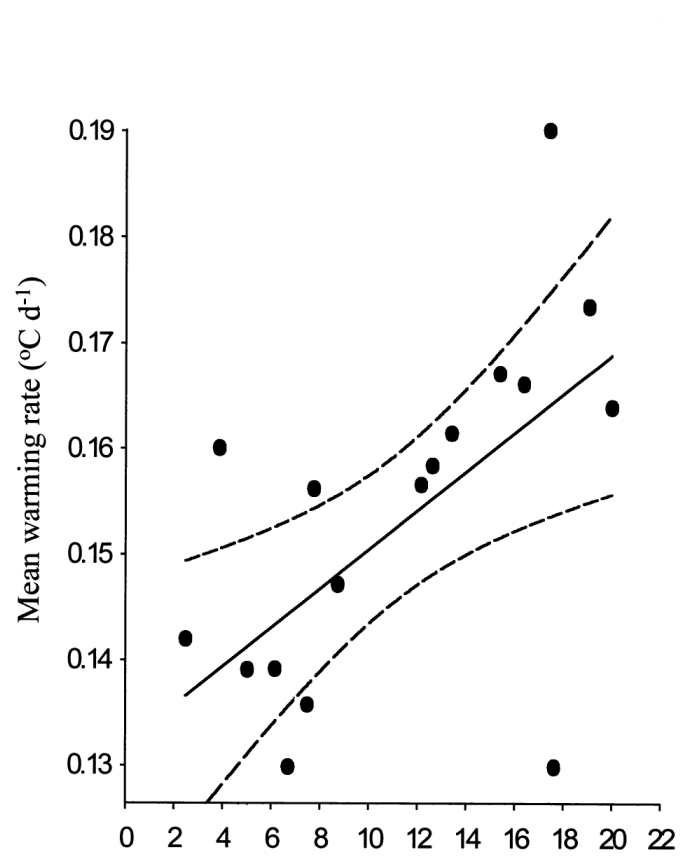

Distance upstream $(\mathrm{km})$

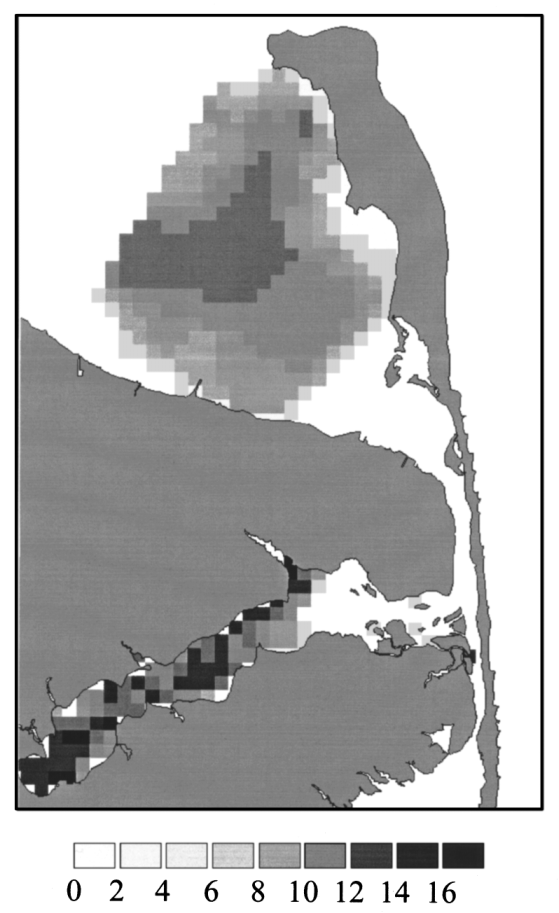

Sediment organic content (\% by wt.) 


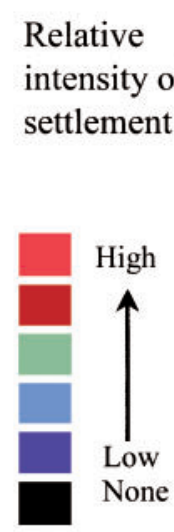

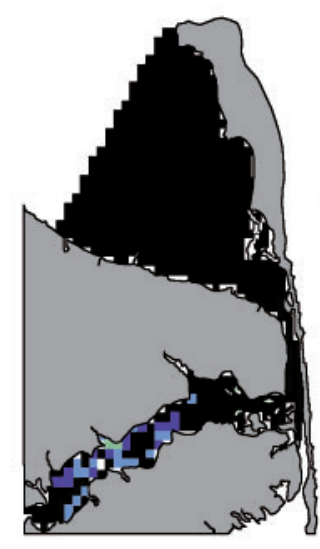

Late April

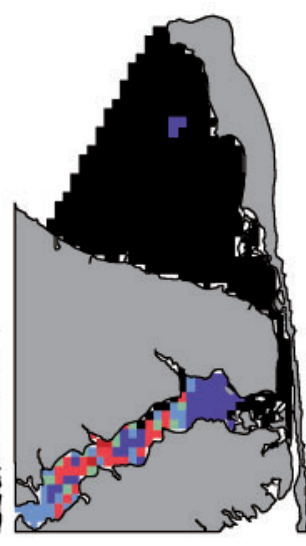

Early May

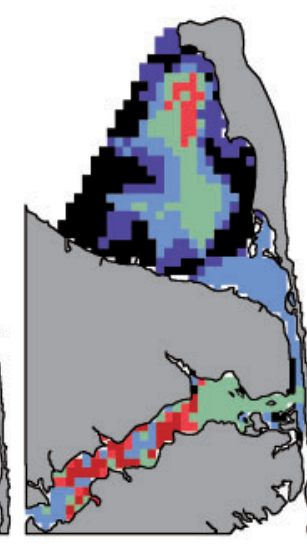

Mid May

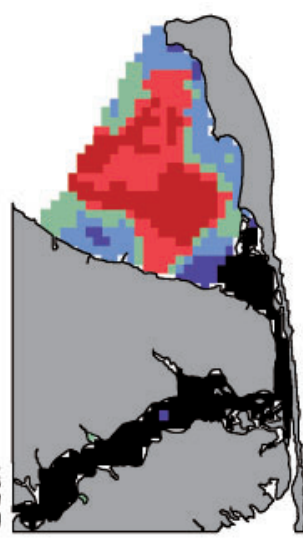

Early June

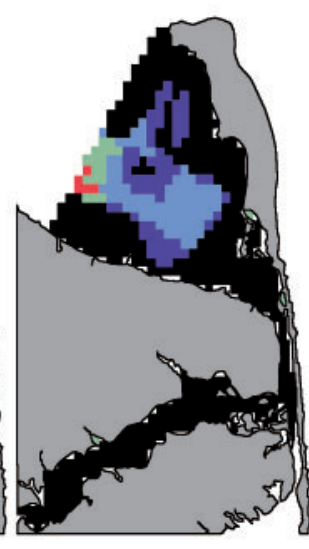

Mid June

xFig. 6. Pseudopleuronectes americanus. Projections of the generalized additive model (GAM; see Table 3, Fig. 4) indicating that the middle reach of the Navesink River and the central portion of Sandy Hook Bay were likely centers for winter flounder settlement, but that recruitment occurred earlier in the river than the bay

the bay $(\mathrm{N}=2)$. The abundance of fish $>20 \mathrm{~mm}$ SL varied among stations within sectors in time in the river (Table 2).

\section{Relationship between settler supply and juvenile distributions}

Patterns of juvenile flounder abundance established at settlement appeared to be modified much more rapidly by post-settlement processes in the bay than the river. Juvenile abundance patterns were not related to settlement in the bay (Fig. 8, Table 4). In the river, however, the index of settler supply explained $95 \%$ of the variation in the average abundance of juveniles. Juvenile distributions were generally correlated with settler supply in the river from April 25 to June 5 (Table 4). When beam-trawled size classes were considered separately, estuary-wide distributions of recently settled fish $\leq 20 \mathrm{~mm}$ SL were related to settler supply from May through mid-June (Spearman's $\rho$ : $0.444-0.822, \mathrm{p}<0.04$ ), while densities of fish $>20 \mathrm{~mm}$ SL and all juveniles were not (Table 4).

Crustacean predators were generally less abundant in the bay than the river and thus probably not responsible for the alteration of the settlement pattern (Fig. 9, Table 2). Blue crabs (median $\mathrm{CW}=17 \mathrm{~mm}$; range $=2$ to 142 ) were rare in the bay. In the river, crab densities varied among sectors and increased upstream. Densities of sand shrimp ( $\geq 30 \mathrm{~mm}$ TL) capable of consuming newly settled flounder varied by region in time. During flounder settlement (April 11to June 19), shrimp densities were slightly higher in the river than the bay, but the regional difference was significant in only 1 survey (June 19; Bonferroni multiple comparison test, $\mathrm{p}=$ 0.001).

\section{DISCUSSION}

\section{Trapping techniques}

Passive collectors have been used to measure variation in settler supply for a variety of marine invertebrates (Yund et al. 1991, Gaines \& Bertness 1993, Eggleston et al. 1998, Moksnes \& Wennhage 2001) and a few site-attached reef fishes (Behrents 1987, Levin 1996, Steele et al. 2002). When effective, collectors integrate densities of competent larvae and fluid flows over discrete periods of time while limiting postsettlement mortality and emigration, and thus provide a relative measure of the flux of potential settlers (Gaines \& Bertness 1993). In contrast, traditional plankton sampling produces snapshots of highly variable densities of pre-competent as well as competent larvae during the dispersal phase. Although fine-mesh trawls only capture settled and thus competent individuals, they also produce snapshots of distributions that may represent settlement patterns that have been dramatically altered by post-settlement processes.

Our traps integrated fluxes of fully competent settlement-stage winter flounder over $13 \mathrm{~d}$ periods while limiting the effects of post-settlement mortality and emigration. The flounder we collected probably entered the traps from competency to less than about $8 \mathrm{~d}$ in post-metamorphic age. The fish had completed metamorphosis, which occurs when larvae reach 7 to $13 \mathrm{~mm}$ SL (Chambers \& Leggett 1987, Able \& Fahay 1998), and grew at an average of $1.3 \mathrm{~mm} \mathrm{SL} \mathrm{d} \mathrm{d}^{-1}$ inside the traps. Sogard et al. (2001) reported similar growth for settling fish collected in Sandy Hook Bay over 9 yr $(\bar{x}=$ 1.12 $\mathrm{SL} \mathrm{mm} \mathrm{d}^{-1}$ ). Since the $3 \mathrm{~mm}$ mesh excluded flounder $>14 \mathrm{~mm} \mathrm{SL} \approx 4 \mathrm{~mm}$ BD from the traps, fish settling 
A) Recently settled fish

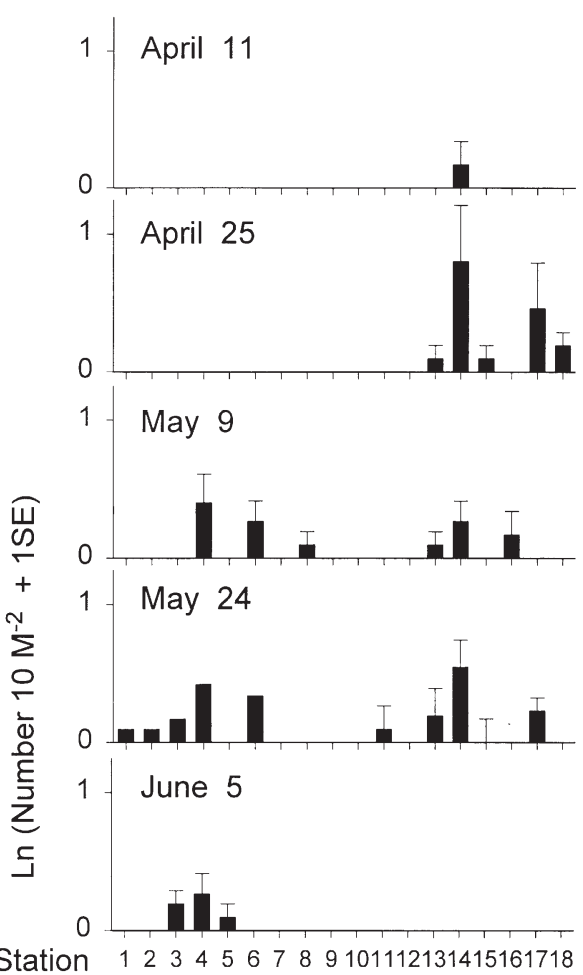

\section{B) Juvenile fish}
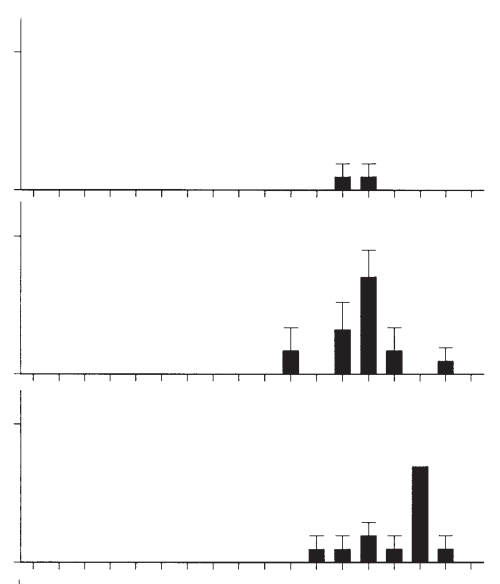

June 19

Station $123 \frac{456}{A} \frac{789}{C} \frac{101112131415161718}{\mathrm{D}}$ Sector

Region

$\frac{\bar{A} \frac{1}{B}}{\text { Bay }}$

River

Fig. 7. Pseudopleuronectes americanus. (A) Abundance in beam trawls for recently settled flounder $<20 \mathrm{~mm}$ SL which were collected earlier in the Navesink River than in Sandy Hook Bay. (B) Juvenile flounder $\geq 20 \mathrm{~mm}$ SL were common in trawls in the river but nearly absent in the bay. (See Fig. 1 for station locations. Surveys in which fish were absent are not included) or mortality of fish inside the traps, and reflected natural settlement patterns. Settler abundance was not correlated with the growth of marked fish inside the traps in the 1999 experiment. The settlement index was probably not biased by mortality, since survivorship for small flounder (16 to $28 \mathrm{~mm} \mathrm{SL}$ ) caged for 10 to $12 \mathrm{~d}$ in enclosures identical to the traps has not been related to natural habitat variation in several growth studies (Able et al. 1999, Manderson et al. 2002). Finally, correlations between the abundance of flounder in traps and trawls suggested that the traps measured natural settlement patterns. Abundance of settlers in traps and fish $<20 \mathrm{~mm}$ SL in trawls were -statistically correlated and broadly similar. In addition, the index of settler supply derived from the traps explained $95 \%$ of the variability in the average abundance of juveniles at stations in the river where post-settlement processes appeared to modify settlement patterns relatively slowly.

\section{Winter flounder settlement dynamics}

Although flounder settled throughout the estuary, we collected large numbers of new recruits in organically rich depositional habitats. Newly settled fish were most consistently trapped and trawled at depositional sites in the river and bay, and our GAM indicated that the abundance of flounder in traps was higher on at the smallest size that grew $1 \mathrm{~mm} \mathrm{SL} \mathrm{d}^{-1}$ were probably unable to enter the gear 7 to $8 \mathrm{~d}$ after metamorphosis. This estimate is within the range of the post-metamorphic ages of the fish we trapped (4 to $14 \mathrm{~d}$ ).

Our trap-based index of settler supply was probably not confounded by post-settlement mortality and emigration. The fine mesh traps retained fish just larger than the maximum size at settlement ( 14 mm SL) and thus minimized emigration. Predators were also excluded by the gear. Although we trapped sand shrimp, the individuals were too small to consume newly settled winter flounder (Witting \& Able 1993, 1995, Bertram \& Leggett 1994).

Our estimates of settler supply also appeared to be unbiased by variations in the habitat-specific growth
Table 4. Pseudopleuronectes americanus. Rank correlation tests (Kendall's $\tau$ ) showing significant relationships between juvenile flounder abundance (beam trawls) and settler supply (cumulative abundance of fish in traps) in the Navesink River (April 25, May 9, June 5) but not in Sandy Hook Bay

\begin{tabular}{|lccccccc|}
\hline \multirow{2}{*}{$\begin{array}{l}\text { Sampling } \\
\text { date }\end{array}$} & \multicolumn{2}{c}{ Study area } & \multicolumn{2}{c}{ River } & \multicolumn{2}{c}{ Bay } \\
& $\tau$ & $\mathrm{p}$ & $\tau$ & $\mathrm{p}$ & $\tau$ & $\mathrm{p}$ \\
\hline April 12 & -0.01 & 0.808 & -0.028 & 0.720 & - & - \\
April 25 & 0.399 & 0.007 & 0.500 & 0.039 & - & - \\
May 9 & 0.333 & 0.019 & 0.556 & 0.011 & 0.1389 & 0.5234 \\
May 24 & 0.222 & 0.173 & 0.417 & 0.099 & 0.3056 & 0.2254 \\
June 5 & 0.275 & 0.082 & 0.638 & 0.009 & 0.4167 & 0.0601 \\
June 19 & -0.059 & 0.594 & 0.167 & 0.444 & - & - \\
July 5 & -0.163 & 0.186 & -0.139 & 0.465 & -0.277 & 0.143 \\
& & & & & & & \\
\hline
\end{tabular}


organically rich substrata. Projections of the GAM described 2 likely centers of winter flounder settlement, located in the middle reach of the river and center of the bay. The locations of these centers were remarkably similar to those reported by Stoner et al. (2001) (their Fig. 6), who also found early juvenile fish ( $<25 \mathrm{~mm} \mathrm{TL}$ ) to be an associated with organically rich substrata ( $>6 \%$ by weight) in their analysis of June trawl surveys conducted in the NSBES in earlier years. Associations of Age 0 winter flounder with depositional muddy substrates has been reported in other estuarine systems as well (Saucerman 1990, Howell et al. 1999, Meng \& Powell 1999) and fish <20 mm SL actively select fine-grained muddy substrates in the laboratory (Phelan et al. 2001).

Flounder settlement occurred approximately 2 wk earlier in the Navesink River (late April through late May) than in Sandy Hook Bay (mid-May through midJune), even though the recruitment centers were just

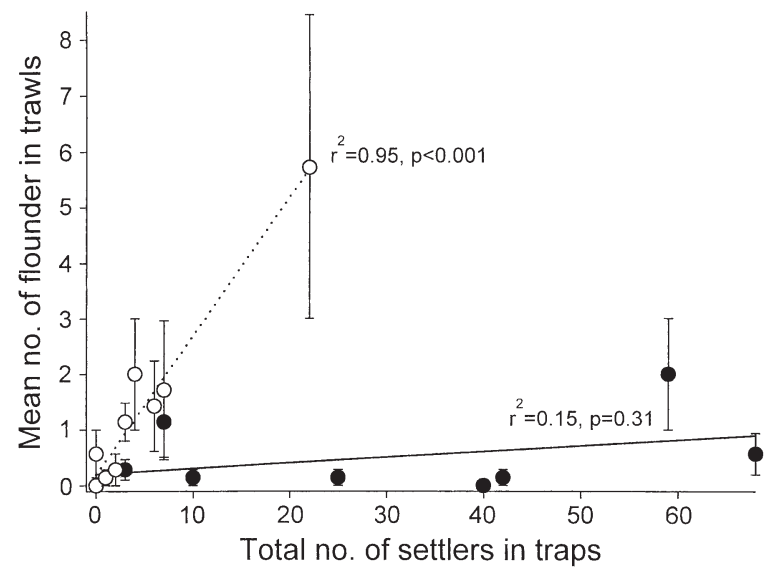

Fig. 8. Pseudopleuronectes americanus. Mean abundance of Age-0 flounder (trawls) was strongly correlated with total settler supply (traps) in the river (O) but not in the bay $(\bullet)$ indicating that settlement patterns were rapidly modified by post-settlement process in Sandy Hook Bay. Lines, $\mathrm{r}^{2}$ and $\mathrm{p}$ values are results of regression analyses

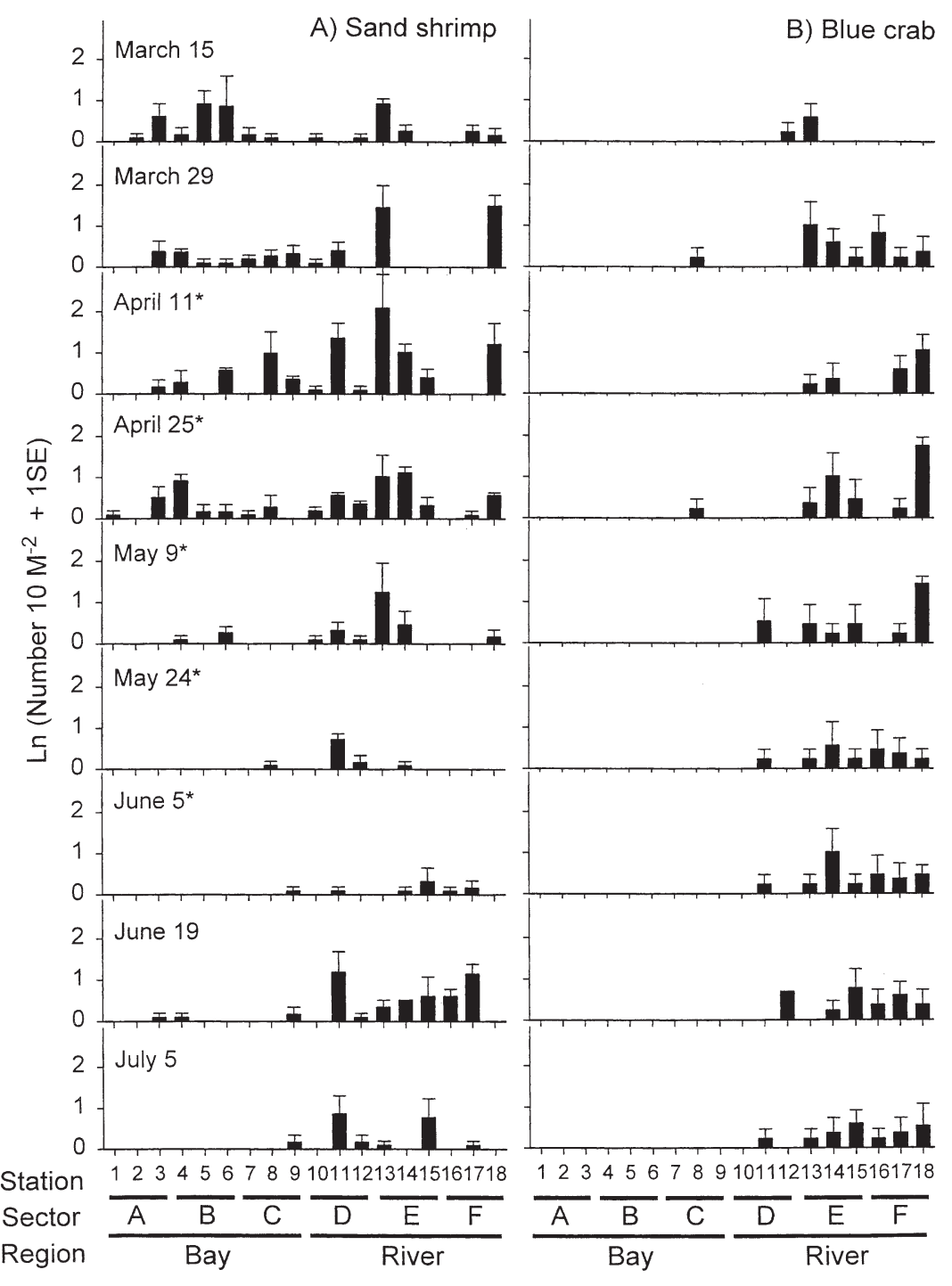

$15 \mathrm{~km}$ apart. In our analysis this fine-scale spatially dynamic settlement pattern was related to geographic variation in spring warming within the estuary. Settler abundance showed a strong unimodal response to TDD which accumulated more rapidly in the river. The importance of temperature history indexed as degree days probably reflected temperature effects on larval stage durations. Stage duration in larval fishes is inversely temperature-dependent (Houde 1989, Chambers \& Leggett 1992, Benoit et al. 2000), and an increase in laboratory incubation temperature from 5 to $8^{\circ} \mathrm{C}$ can shorten the winter flounder larval period by $31 \mathrm{~d}$ (Laurence 1975).

The relationship between flounder settlement dynamics and geographic variation in spring warming with the estuary indicates that substantial numbers of larvae were probably segregated in the river and bay for long enough that regional temperature differences influenced larval stage durations. Previous studies of flounder spawning and circulation in the estuary support this hypothesis. Adult fish spawn in the middle and upper reaches of

Fig. 9. (A) Sand shrimp (TL $\geq 30 \mathrm{~mm} \mathrm{TL}$ ) and (B) blue crabs were generally more abundant in the river than in the bay and thus probably not responsible for the alteration of the winter flounder settlement pattern. ${ }^{*}$ Experiments in which newly settled flounder were collected in trawls and/or settlement traps (see Fig. 1 for station locations) 
the Navesink River from February through March (Phelan 1992, Stoner et al. 1999), and ripe adults are collected in Sandy Hook Bay during the same months (Chambers \& Witting pers. comm.). Larvae hatching in the river are likely to be retained there because flooddominated tidal circulation results in upstream transport to the middle reach (Chant \& Stoner 2001). In Sandy Hook Bay residual tidal circulation produces a cyclonic gyre that concentrates particles and may promote larval retention near the center of the bay (Hires \& Mellor 1988). Associations of early juvenile winter flounder with organically rich depositional habitats in the NSBES and other estuaries may be partially related to circulation mechanisms that maintain depositional habitats and concentrate larvae in the vicinity of them.

Flounder settlement was related to temperature and substrate characteristics in our study, but a considerable amount of the variation remained unexplained. This is not surprising since settlement can be controlled by a suite of factors not measured or considered in our analysis, including the location and timing of spawning and egg hatching; meteorological and hydrographic processes that influence larval dispersal; larval mortality, prey densities and swimming behavior; and active habitat selection by larvae competent to settle (Norcross \& Shaw 1984, Breitberg et al. 1995, Dame \& Allen 1996, Sponaugle \& Cowen 1996, Cowen \& Sponaugle 1997, Wennhage \& Gibson 1998, Bradbury \& Snelgrove 2001).

Modifications of settlement patterns by post-settlement processes

In our study the upstream distribution of juvenile flounder was not produced by geographic variation in the total supply of potential new recruits, but by spatial variation in the rate at which the settlement pattern was modified by post-settlement processes. Our trap data suggested that settlement was nearly an order of magnitude higher in Sandy Hook Bay than in the Navesink River. Nevertheless, flounder $>20 \mathrm{~mm}$ SL were rarely trawled in the bay, where juvenile abundance was not correlated with settlement. In contrast, larger juveniles were common in the river, where the index of settlement explained $95 \%$ of the variation in average flounder abundance. Age 0 flounder are consistently more abundant and generally larger upstream in the Navesink River than in Sandy Hook Bay in early summer trawl surveys (Fig. 10). Age 0 fish are distributed upstream in other estuaries as well (Pearcy 1962, Armstrong 1995, Meng \& Powell 1999). In the NSBES, the formation of the upstream nursery ground appears to be the result of particularly rapid modification of winter flounder settlement patterns by post-settlement processes in the bay.
We were unable to directly measure juvenile emigration and mortality and therefore identify the specific post-settlement process(es) that modified the settlement pattern. Fish may have emigrated upstream into the river or toward shallow shoreline habitats from settlement sites in the bay. Although a mark-recapture study indicated that young flounder (20 to $80 \mathrm{~mm} \mathrm{TL}$ ) rarely move from nursery habitats (Saucerman \& Deegan 1991), Pearcy (1962) and Witting (1995) used trawl data to argue that fish emigrate rapidly from settlement sites. Pearcy (1962) suggested that fish migrate upstream following settlement because the abundance of newly settled flounder declined at sites in the lower Mystic River, Connecticut, as densities of larger fish increased upstream. Similar upstream movements are exhibited by early juveniles of a Northern European flatfish (Platichthys flesus; Kerstan 1991). However, upstream migration was not evident in our study since flounder densities were consistently low in the inner bay and lower river and did not increase in the river over time. Newly settled flounder may also move to shallow areas as they age and grow (Armstrong 1997, Stoner et al. 2001), and fish settling in deeper bay habitats may have emigrated more rapidly to shorelines than from shallower settlement areas in the river. Since we did not sample shallow shoreline habitats in this study, we cannot rule out the possibility that setters emigrated to shallow areas at higher rates in the bay. However, in Stoner et al.'s (2001) spatially comprehensive study of the NSBES, juvenile winter flounder were less likely to occur in shallow bay areas than in habitats of similar depth in the river.

Predation is thought to be the leading cause of mortality for newly settled fishes (Bailey 1994, van der Veer et al. 1997, Connell 1998, Dahlgren \& Eggleston 2000), and mortality rates for recently settled flounder may have been higher in the bay than the river. Shrimp of the genus Crangon and crabs consume newly settled flatfishes, including winter flounder, in the field and laboratory (Macer 1967, Edwards \& Steele 1968, van der Veer \& Bergman 1987, Seikai et al. 1993, Bertram \& Leggett 1994, Witting 1995, Witting \& Able 1995, Ansell et al. 1999, Fairchild \& Howell 2000). In our study, however, modification of the settlement pattern was not related to density variations of shrimp and blue crabs, which were equally or more abundant in the river than the bay. Fishes are also important predators of early juvenile flatfishes on some nursery grounds (Edwards \& Steele 1968, Ellis \& Gibson 1995) and migratory fish including striped searobin Prionotis evolans, summer flounder Paralychthys dentatus, red hake Urophycis regia, striped bass Morone saxatilis, and bluefish Pomatomus saltatrix consume winter flounder (Poole 1964, Juanes et al. 1993, Manderson et al. 1999, 2000, North East Fisheries Science 


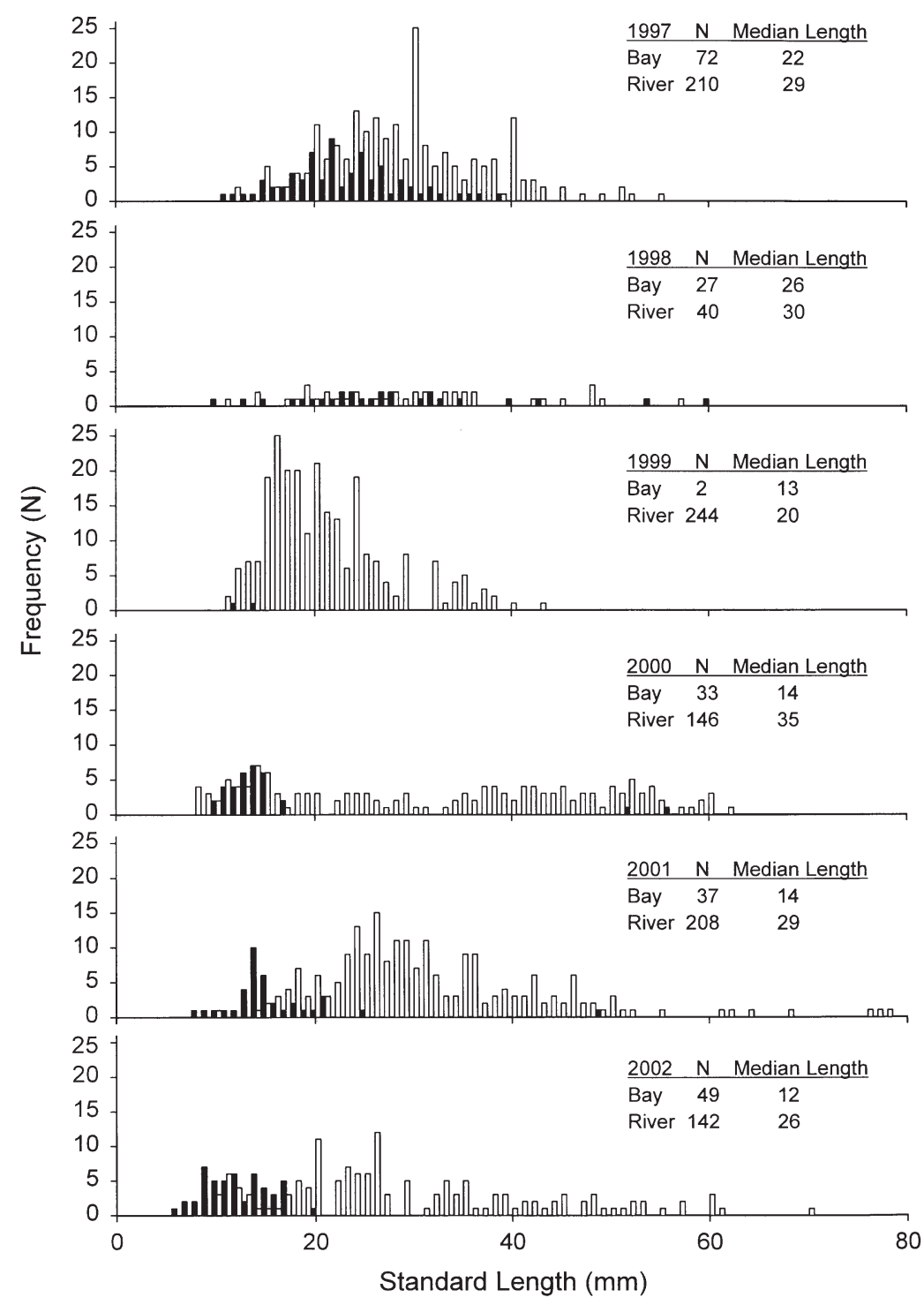

Fig. 10. Pseudopleuronectes americanus. From 1997 through 2002 Age 0 winter flounder were generally larger in size and more abundant in the Navesink River (white bars) than in Sandy Hook Bay (black bars) in May through early June trawl surveys of estuary

Center unpubl. data). With the exception of hake, all of these species enter the NSBES through the bay in the spring and early summer. Sea robins and hakes consume large numbers of newly settled fish $(<20 \mathrm{~mm}$ SL) in the NSBES and are generally more abundant in the bay (Manderson et al. 1999, J.P.M. unpubl. data). Predation pressure exerted by fish could have been higher in the bay for at least a short period during and immediately following flounder settlement. However, spatial differences in the availability of structurally complex refuge habitats composed of vegetation or woody debris, which are more common in the river, could have affected survivorship independently of predator density.

\section{CONCLUSION}

Our goal in this study was to assess the relative contributions of supply side and post-settlement processes to the formation of juvenile winter flounder distributions and the primary nursery ground in a mid-Atlantic estuarine system. In our experiment, the upstream distribution of young flounder was produced by the modification of settlement patterns by post-settlement processes rather than spatial variation in the total supply of potential new recruits. However, variation in habitat characteristics that influence larval traits, including settlement timing, can strongly influence the ways in which post-settlement processes affect early juveniles. For example, juvenile survivorship for some coral reef fishes and European flatfish is related to larval characteristics including settlement timing (Al-Hossaini et al. 1989, Modin \& Pihl 1996, Searcy \& Sponaugle 2001, Bergenius et al. 2002). Our study indicates that the combined effects of local heterogeneity in hydrographic retention mechanisms and temperatures on larval development rates may produce finescale spatial $(\sim 10 \mathrm{~km})$ and temporal (wk) variability in larval settlement for winter flounder, a species that uses natal estuaries as juvenile nurseries. Specifically, fish settled earlier in a rapidly warming upstream estuarine region where juvenile distributions reflected settlement for a relatively long period of time. In an earlier study we showed that early spring warming combined with optimal salinities and prey densities promoted rapid growth in early juvenile winter flounder within this same region for a limited period during the late spring (Manderson et al. 2002). Early settlement combined with the rapid early growth in the upper estuary probably produces winter flounder body-size variations we generally observe (Fig. 10), and could strongly affect the ways in which size as well as timeand age-dependent post-settlement processes shape early juvenile distributions. Work presented here and in our earlier growth study suggests that environmental conditions in the upper reaches of estuaries may favorably affect critical supply-side and early post-settlement processes, and ultimately promote the survivorship of winter flounder through the early juvenile stage. 
Acknowledgements. The authors would like to thank John Rosendale, Don McMillan, Peter Clarke, and Larry Brady for their help in the field and laboratory. Special thanks go to Allen Bejda, John Boreman, Mary Fabrizio, Francis Juanes, Don Kroodsma, Beth Phelan, Fred Scharf, Linda Stehlik and Allan Stoner for their valuable advice and/or reviews of the manuscript.

\section{LITERATURE CITED}

Able KW, Fahay MP (1998) The first year in the life of estuarine fishes in the Middle Atlantic Bight. Rutgers University Press, New Brunswick, NJ

Able KW, Manderson JP, Studholme AL (1999) Habitat quality for shallow water juvenile fishes in an urban estuary: the effects of manmade structures on the growth of winter flounder and tautog in the lower Hudson River estuary. Mar Ecol Prog Ser 187:227-235

Al-Hossaini M, Liu Q, Pitcher TJ (1989) Otolith microstructure indicating growth and mortality among plaice, Pleuronectes platessa L., post-larval sub-cohorts. J Fish Biol 35:81-90

Ansell AD, Comely CA, Robb L (1999) Distribution, movements and diet of macrocrustaceans on a Scottish sandy beach with particular reference to predation on juvenile fishes. Mar Ecol Prog Ser 176:115-130

Armstrong MP (1995) A comparative study of the ecology of smooth flounder Pleuronectes putami, and winter flounder, Pleuronectes americanus from Great Bay, New Hampshire. PhD thesis, University of New Hampshire, Durham, NH

Armstrong MP (1997) Seasonal and ontogenetic changes in distribution and abundance of smooth flounder Pleuronectes putnami, and winter flounder, Pleuronectes americanus, along estuarine depth and salinity gradients. Fish Bull 95:414-430

Bailey KM (1994) Predation on juvenile flatfish and recruitment variability. Neth J Sea Res 32:175-189

Behrents KC (1987) The influence of shelter availability on recruitment and early juvenile survivorship of Lythroypnus dalli Gilbert (Pisces: Gobiidae). J Exp Mar Biol Ecol 107:45-59

Benoit DF, Pepin P, Brown JA (2000) Patterns of metamorphic age and length in marine fishes, from individuals to taxa. Can J Fish Aquat Sci 57:856-869

Bergenius MAJ, Meekan MG, Robertson DR, McCormick MI (2002) Larval growth predicts the recruitment success of a coral reef fish. Oecologia 131:521-525

Bertram DF, Leggett WC (1994) Predation risk during the early life history periods of fishes: separating the effects of size and age. Mar Ecol Prog Ser 109:105-114

Beverton RJH, Iles TC (1992) Mortality rates of 0-group plaice (Pleuronectes platessa L.), dab (Limanda limanda) and turbot (Scopthalmus maximus L.) in European waters. III. Density dependent mortality rates of 0 -group plaice and some demographic implications. Neth J Sea Res 29:61-79

Booth DJ (2002) Distribution changes after settlement in 6 species of damselfish (Pomacentridae) in One Tree Island lagoon, Great Barrier Reef. Mar Ecol Prog Ser 226:157-164

Bradbury IR, Snelgrove PVR (2001) Contrasting larval transport in demersal fish and benthic invertebrates: the roles of behavior and advective processes in determining spatial pattern. Can J Fish Aquat Sci 58:811-823

Breitberg DL, Palmer MA, Loher T (1995) Larval distributions and the spatial patterns of settlement of an oyster reef fish: responses to flow and structure. Mar Ecol Prog Ser 125: $45-60$
Caselle JE, Warner RR (1996) Variability in recruitment of coral reef fishes: the importance of habitat at two spatial scales. Ecology 77:2488-2504

Chambers RC, Leggett WC (1987) Size and age at metamorphosis in marine fishes: an analysis of laboratory reared winter flounder (Pseudopleuronectes americanus) with a review of variation in other species. Can J Fish Aquat Sci 44:1936-1947

Chambers RC, Leggett WC (1992) Possible causes and consequences of variation in age and size at metamorphosis in flatfishes (Pleuronectiformes): an analysis at the individual, population and species levels. Neth J Sea Res 29:7-24

Chambers RC, Witting DA, Lewis SJ (2001) Detecting critical periods in larval flatfish populations. Neth J Sea Res 45: 231-242

Chant RJ, Stoner A (2001) Particle trapping in a stratified flood dominated estuary. J Mar Res 59:29-51

Chant RJ, Curran MC, Able KW, Glenn SM (2000) Delivery of winter flounder (Pseudopleuronectes americanus) larvae to settlement habitats in coves near tidal inlets. Estuar Coast Shelf Sci 51:529-541

Connell SD (1998) Effects of predators on growth, mortality and abundance of a juvenile reef fish: evidence from manipulations of predator and prey abundance. Mar Ecol Prog Ser 169:251-261

Cowen RK, Sponaugle S (1997) Relationship between early life history traits and recruitment among coral reef fishes. In: Chambers RC, Trippel EA (eds) Early life history and recruitment in fish populations. Chapman \& Hall, London, p 423-449

Crawford RE, Kerry CG (1985) Retention of winter flounder larvae within a Rhode Island salt pond. Estuaries 8: $217-227$

Dahlgren CP, Eggleston DB. (2000) Ecological processes underlying ontogenetic habitat shifts in a coral reef fish. Ecology 81:2227-2240

Dame RF, Allen DM (1996) Between estuaries and the sea. J Exp Mar Biol Ecol 200:169-185

Edwards RRC, Steele JH (1968) The ecology of 0-group plaice and dabs at Loch Ewe. I. Population and food. J Exp Mar Biol Ecol 2:215-238

Eggleston DB, Lipcius RN, Marshall LS, Hines AH (1998) Spatiotemporal variation in postlarval recruitment of the Caribbean spiny lobster in the central Bahamas: lunar and seasonal periodicity, spatial coherence, and wind forcing. Mar Ecol Prog Ser 174:33-49

Ellis T, Gibson RN (1995) Size-selective predation of 0-group flatfish on a Scottish nursery ground. Mar Ecol Prog Ser $127: 27-37$

Fairchild EA, Howell WH (2000) Predator-prey size relationship between Pseudopleuronectes americanus and Carcinus maenas. J Sea Res 44:81-90

Folk RL (1980) Petrology of sedimentary rocks. Hemphill Publishing, Austin

Gaines SD, Bertness MD (1993) The dynamics of juvenile dispersal: why field ecologists must integrate. Ecology 74 : $2430-2435$

Hastie TJ (1992) Generalized additive models. In: Chambers JM, Hastie TJ (eds) Statistical models in S. Chapman \& Hall, New York, p 249-307

Hastie TJ, Tibshirani RJ (1990) Generalized additive models. Chapman \& Hall, London

Hines AH, Ruiz GM (1995) Temporal variation in juvenile blue crab mortality: nearshore shallows and cannibalism in Chesapeake Bay. Bull Mar Sci 57:884-901

Hires RI, Mellor GL (1988) Numerical model studies of circulation in the Hudson-Raritan estuary. In: NOAA Estuary 
of the Month Series \#9. Hudson/Raritan Estuary: issues, resources, status and management. NOAA Estuarine Programs Office, Washington, DC, p 27-43

Houde ED (1987) Fish early life dynamics and recruitment variability. Am Fish Soc Symp 2:17-29

Houde ED (1989) Comparative growth, mortality, and energetics of marine fish larvae: temperature and implied latitudinal effects. Fish Bull US 87:471-495

Howe AB, Coates PG, Pierce DE (1976) Winter flounder estuarine year-class abundance, mortality and recruitment. Trans Am Fish Soc 105:647-657

Howell PT, Molnar DR, Harris RB(1999) Juvenile winter flounder distribution by habitat type. Estuaries 22:1090-1098

Jager Z, Kleef HL, Tydeman P (1995) Mortality and growth of 0 -group flatfish in the brackish Dollard (EMS estuary, Wadden Sea). Neth J Sea Res 34:119-129

Juanes F, Marks RE, McKown KA, Conover DO (1993) Predation by Age-0 bluefish on Age-0 anadromous fishes in the Hudson River Estuary. Trans Am Fish Soc 122:348-356

Keller AA, Klein-MacPhee G, Burns JS (1999) Abundance and distribution of ichthyoplankton in Narragansett Bay, Rhode Island, 1989-1990. Estuaries 22:149-163

Kerstan M (1991) The importance of rivers as nursery grounds for 0- and 1-group flounder (Platichthys flesus L.) in comparison to the Wadden Sea. Neth J Sea Res 27:353-366

Laurence SC (1975) Laboratory growth and metabolism of the winter flounder Pseudopleuronectes americanus from hatching through metamorphosis at three temperatures. Mar Biol 32:223-229

Levin PS (1994) Fine-scale recruitment variation in a temperate dimersal fish: the importance of settlement and postsettlement processes. Oecologia 97:124-133

Levin PS (1996) Recruitment of a temperate demersal fish: does larval supply matter. Limnol Oceanogr 41:672-679

Lobell MJ (1939) A biological survey of the salt waters of Long Island, 1938. Report on certain fishes. Winter flounder (Pseudopleuronectes americanus). 28th Annu Rep NY Conserv Dept, Part I (Suppl) 14:63-96

Macer CT (1967) The food web in Red Wharf Bay (North Wales) with particular reference to young plaice (Pleuronectes platessa). Helgol Mar Res 15:560-573

Manderson JP, Stoner AW, Stehlick LL (1997) Species responses to environmental gradients and the description of estuarine landscape patterns. ICES Annual Science Conference. ICES CM/1997, Baltimore

Manderson JP, Phelan BA, Bejda AJ, Stehlik LL, Stoner AW (1999) Predation by striped searobin (Prionotis evolans, Triglidae) on young-of-the-year winter flounder (Pseudopleuronectes americanus, Walbaum): examining prey size selection and prey choice using field observations and laboratory experiments. J Exp Mar Biol Ecol 242: 211-231

Manderson JP, Phelan BA, Stoner AW, Hilbert J (2000) Predator-prey relations between age 1+ summer flounder (Paralichthys dentatus, Linnaeus) and age-0 winter flounder (Pseudopleuronectes americanus, Walbaum): predator diets, prey selection, and effects of sediments and macrophytes. J Exp Mar Biol Ecol 251:17-39

Manderson JP, Phelan BA, Meise C, Stehlik LL and 5 others (2002) Spatial dynamics of habitat suitability for growth of newly-settled winter flounder in an estuarine nursery. Mar Ecol Prog Ser 228:227-239

Meng L, Powell JC (1999) Linking juvenile fish and their habitats: an example from Narragansett Bay, Rhode Island. Estuaries 22:905-916

Modin J, Pihl L (1996) Small scale distribution of juvenile plaice and flounder in relation to predatory shrimp in a shallow Swedish bay. J Fish Biol 49:1070-1085

Moksnes PO (2002) The relative importance of habitatspecific settlement, predation and juvenile dispersal for distribution and abundance of young juvenile shore crabs Carcinus maenas L. J Exp Mar Biol Ecol 271:41-73

Moksnes PO, Wennhage H (2001) Methods for estimating decapod larval supply and settlement: importance of larval behaviour and development stage. Mar Ecol Prog Ser 209:257-273

Nash RDM, Geffen AJ (2000) The influence of nursey ground processes in the determination of year class strength in juvenile plaice, Pleuronectes platessa L. in Port Erin Bay, Irish Sea. J Sea Res 44:101-110

Norcross BL, Shaw RF (1984) Oceanic and estuarine transport of fish eggs and larvae: a review. Trans Am Fish Soc 113: 153-165

Pearcy WG (1962) Ecology of an estuarine population of winter flounder Pseudopleuronectes americanus (Walbaum). Parts I-IV. Bull Bingham Oceanogr Collect 18:1-77

Pereira JJ, Goldberg R, Ziskowski JJ, Berrien PL, Morse WW, Johnson DL (1999) Winter flounder, Pseudopleuronectes americanus, life history and habitat characteristics. NOAA Tech Mem NMFS-NE-138, Woods Hole, MA

Perlmutter A (1947) The blackback flounder and its fishery in New England and New York. Bull Bingham Oceanogr Collect 11:1-92

Phelan BA (1992) Winter flounder movements in the inner New York Bight. Trans Am Fish Soc 121:777-784

Phelan BA, Manderson JP, Stoner AW, Bejda AJ (2001) Sizerelated shifts in the habitat associations of young-of-theyear winter flounder (Pseudopleuronectes americanus): field observations and laboratory experiments with sediments and prey. J Exp Mar Biol Ecol 257:297-315

Pierce DE, Howe AB (1977) A further study on winter flounder group identification off Massachusetts. Trans Am Fish Soc 106:131-139

Poole JC (1964) Feeding habits of summer flounder in Great South Bay. NY Fish Game J 11:28-34

Saila S (1961) A study of winter flounder movements. Limnol Oceanogr 6:292-298

Saucerman SE (1990) Movement, distribution and productivity of post metamorphic winter flounder (Pseudopleuronectes americanus) in different habitat types in Waquuiot Bay, Massachusetts. Msc thesis, University of Massachussets, Amherst, MA

Saucerman SE, Deegan LA (1991) Lateral and cross channel movement of young-of-the-year winter flounder (Pleuronectes americanus) in Waquoit Bay, Massachusetts. Estuaries 14:440-446

Scarlett PG (1991) Temporal and spatial distribution of winter flounder (Pseudopleuronectes americanus) spawning in the Navesink and Shrewsbury Rivers, New Jersey. Report to the New Jersey Department of Environmental Protection, Division of Fish, Game and Wildlife, Marine Fisheries Administration, Bureau of Marine Fisheries, Trenton, NJ. New Jersey Department of Environmental Protection

Searcy SP, Sponaugle S (2001) Selective mortality during the larval-juvenile transition in two coral reef fishes. Ecology 82:2452-2470

Seikai T, Kinoshita I, Tanaka M (1993) Predation by crangonid shrimp on juvenile Japanese flounder under laboratory conditions. Nippon Suisan Gakkaishi 59:321-326

Shima JS (2001) Recruitment of a coral reef fish: roles of settlement, habitat, and postsettlement losses. Ecology 82: 2190-2199

Sogard SM (1991) Interpretation of otolith microstructure in juvenile winter flounder (Pseudopleuronectes america- 
nus): ontogenetic development, daily increment validation, and somatic growth relationships. Can J Fish Aquat Sci 48:1862-1871

Sogard SM, Able KW, Hagan SM (2001) Long term assessment of settlement and growth of juvenile winter flounder (Pseudopleuronectes americanus) in New Jersey estuaries. Neth J Sea Res 45:189-204

Sponaugle S, Cowen RK (1996) Larval supply and patterns of recruitment for two Caribbean fishes, Stegastes partitus and Acanthurus bahianus. Mar Freshw Res 47:433-447

Steele MA, Forrester GE (2002) Early postsettlement predation on three reef species: effects on spatial patterns of recruitment. Ecology 83:1076-1091

Steele MA, Malone JC, Findlay AM, Carr MH, Forrester GE (2002) A simple method for estimating larval supply in reef fishes and a preliminary test of population limitation by larval delivery in the kelp bass Paralabrax clathratus. Mar Ecol Prog Ser 235:195-203

Stehlik LL, Meise CJ (2000) Diet of winter flounder in a New Jersey estuary: ontogenetic change and spatial variation. Estuaries 23:381-391

Stoner AW, Bejda AJ, Manderson JP, Phelan BA, Stehlik LL, Pessutti JP (1999) Behavior of winter flounder (Pseudopleuronectes americanus) during the reproductive season: laboratory and field observations on spawning, feeding, and locomotion. Fish Bull 97:999-1016

Stoner AW, Manderson JP, Pessutti J (2001) Spatially-explicit analysis of estuarine habitat for juvenile winter flounder (Pseudopleuronectes americanus): combining generalized additive models and geographic information systems. Mar Ecol Prog Ser 213:253-271

van der Veer HW (1986) Immigration, settlement and densitydependent mortality of a larval and early post-larval 0-group plaice (Pleuronectes platessa) population in the Danish Wadden Sea. Mar Ecol Prog Ser 29:223-236

van der Veer HW, Bergman MJN (1987) Predation by crustaceans on a newly settled 0-group plaice Pleuronectes platessa population in the western Wadden Sea. Mar Ecol Prog Ser 35:203-215

van der Veer HW, Ellis T, Miller JM, Pihl L, Rijnsdorp AD (1997) Size-selective predation on juvenile north sea flat-

Editorial responsibility: Otto Kinne (Editor),

Oldendorf/Luhe, Germany fish and possible implications for recruitment. In: Chambers RC, Trippel EA (eds) Early life history and recruitment in fish populations. Chapman \& Hall, London, p 279-301

van der Veer HW, Geffen AJ, Witte JIJ (2000) Exceptionally strong year classes in plaice Pleuronectes platessa: are they generated during the pelagic stage only, or also in the juvenile stage. Mar Ecol Prog Ser 199:255-262

Venables WN, Ripley BD (1997) Modern applied statistics with S-Plus. Springer-Verlag, New York

Webster MS (2002) Role of predators in the early postsettlement demography of coral-reef fishes. Oecologia 131:52-60

Wennhage H (2002) Vulnerability of newly settled plaice (Pleuronectes platessa L.) to predation: effects of habitat structure and predator functional response. J Exp Mar Biol Ecol 269:129-145

Wennhage H, Gibson RN (1998) Influence of food supply and a potential predator (Crangon crangon) on settling behavior of place (Pleuronectes platessa). J Sea Res 39:103-112

Wennhage H, Pihl L (2001) Settlement patterns of newly settled plaice (Pleuronectes platessa) in a non-tidal Swedish fjord in relation to larval supply and benthic predators. Mar Biol 139:877-889

Wilkerson L (1997) Systat 7.0: statistics. SPSS, Chicago

Witting DA (1995) Settlement of winter flounder, Pleuronectes americanus, in a southern New Jersey estuary: spatial and temporal dynamics and the effect of decapod predation. PhD thesis, Rutgers University, New Brunswick, NJ

Witting DA, Able KW (1993) Effects of body size on probability of predation for juvenile summer and winter flounder based on laboratory experiments. Fish Bull 91:577-581

Witting DA, Able KW (1995) Predation by sevenspine bay shrimp Crangon septemspinosa on winter flounder Pleuronectes americanus during settlement: laboratory observations. Mar Ecol Prog Ser 123:23-31

Yund PO, Gaines SD, Bertness MD (1991) Cylindrical tube traps for larval sampling. Limnol Oceanogr 36:1167-1177

Zijlstra JJ, Dapper R, Witte JIJ (1982) Settlement, growth and mortality of post-larval plaice (Pleuronectes platessa L.) in the western Wadden Sea. Neth J Sea Res 15:250-272

Submitted: January 11, 2002; Accepted: January 31, 2003

Proofs received from author(s): April 24, 2003 